\title{
Multiple Osteochondromas
}

National Cancer Institute

\section{Source}

National Cancer Institute. Multiple Osteochondromas. NCI Thesaurus. Code C53457.

An autosomal dominant neoplastic chondrogenic process affecting multiple sites. It is caused by mutations in the EXT1 or EXT 2 genes. Grossly and microscopically, the lesions resemble an osteochondroma. 